Creative Commons User License: CC BY-NC-ND

Abstracted by: EBSCOhost, Electronic Journals Service (EJS),

Google Scholar, Journal Seek, Scientific Commons,

Food and Agricultural Organization (FAO), CABI and Scopus

http://eoi.citefactor.org/10.11226/v25i4
Journal of Agricultural Extension

Vol. 25 (4) October, 2021

ISSN(e): 24086851; ISSN(Print); $1119944 X$

http://journal.aesonnigeria.org

http://www.ajol.info/index.php/jae

Email: editorinchief@aesonnigeria.org

\title{
Workplace Conflict and Employees' Job Performance in Agro-Services Corporation, Ogun State, Nigeria
}

https://dx.doi.org/10.4314/jae.v25i4.5

\author{
Ayinde, Adefunke Fadilat \\ Department of Agricultural Administration, \\ College of Agricultural Management and Rural Development (COLAMRUD), \\ Federal University of Agriculture, Abeokuta, Nigeria. \\ Email: fadilatayinde@gmail.com; Phone: +2348035022359

\section{Bolarinwa, Kamilu Kolade} \\ Department of Agricultural Administration, \\ College of Agricultural Management and Rural Development, \\ Federal University of Agriculture, Abeokuta, Nigeria. \\ Email: bkolade@gmail.com; Phone: 08062403148
}

\author{
Alarima, Cornelius Idowu \\ Department of Agricultural Extension and Rural Development, \\ College of Agricultural Management and Rural Development, \\ Federal University of Agriculture, Abeokuta, Nigeria. \\ Email: corneliusalarima@yahoo.com; Phone: 08036987418

\section{Kazeem, Saheed Oluwatobi} \\ Department of Agricultural Extension and Rural Development, \\ University of Ibadan, Nigeria. \\ Email: kazeemoluwatobi11@gmail.com; Phone: 07055675704 \\ Kareem, Hakeem Temitope \\ Department of Agricultural Extension and Rural Development, \\ University of Ibadan, Nigeria. \\ Email: abhakeem10@yahoo.com; Phone: 07063379638
}

\section{Abstract}

The study determined the effects of workplace conflict on employees' job performance in Ogun State Agro-service Corporation (OGASC). Multistage sampling technique was used to select 77 respondents. Data were collected through the administration of questionnaires and were analysed using frequency, percentage, and mean. The presence of functional staff union to minimize conflict $(\bar{x}=2.99)$ ranked as the first indication of reduced conflict, followed by existence of favouritism $(\bar{x}=2.51)$ which was ranked highest as an indication of conflict escalating factor by the respondents. Job performance of the respondents was not adversely affected by the workplace conflict they experienced. Therefore, the management of OGASC should ensure improvement in the deployment of the 
Creative Commons User License: CC BY-NC-ND

Abstracted by: EBSCOhost, Electronic Journals Service (EJS),

Google Scholar, Journal Seek, Scientific Commons,

Food and Agricultural Organization (FAO), CABI and Scopus

http://eoi.citefactor.org/10.11226/v25i4
Journal of Agricultural Extension

Vol. 25 (4) October, 2021

ISSN(e): 24086851; ISSN(Print); 1119944X

http://journal.aesonnigeria.org

http://www.ajol.info/index.php/jae

Email: editorinchief@aesonnigeria.org

used resolution strategies to drastically reduce conflict for better performance of the employees.

Keywords: Workplace conflict; employees' performance; agro-services corporation;

\section{Introduction}

When people work as a group, conflict is one of the most predictable outcomes. Most managers spend a lot of their working time dealing with conflicts or fallouts from peoplerelated problems. Mismanagement of conflicts leads to waste of energy that could have been used for productive endeavours (Utaka and Silas-Dikibo, 2020). It is difficult to calculate the losses related to organisational conflict. According to Oachesu (2016), conflict is complex, because at minimum it involves the interaction of cognitive, psychological, physiological, and contextual dynamics. Most conflict theories take only a psychological and/or an economic approach to understanding and managing conflict. Zahid, (2017) opined that conflict is an unpleasant situation that leads to unhealthy competition among employees for assignment, resources, power, recognition and security. Conflict can be regarded as a dispute that occurs when interests, goals or values of different individuals or groups are incompatible with each other. This results in a situation whereby they are frustrated with each other in an attempt to achieve their objectives. Employees who seek power therefore struggle with others for position or status within the group. Conflicts are endemic to society as a whole. They are directly related to the scarcity of resources, division of functions and tasks, power of relations, differentiation and organisation roles in society. According to Oachesu (2016), any organisation, regardless of its type (public institution, state-owned commercial organisation or private non-profit organisation, etc.), face daily conflicts that are based on different causes of internal and external organization which can affect their job performance on different scales.

Employees' performance is influenced by a lot of aspects such as motivation, work environment and leadership in the agency. An employee's workplace environment is a key determinant of the quality of their work and their level of productivity. Job performance is a very considerable factor influencing profitability of any organisation (Osborne and Hammoud, 2017. Performance is important for organisations as employees' performance leads to business success. Also, performance is important for individuals, as achieving tasks can be a source of satisfaction (Hee, Shi, Kowang, Fei and Ping, 2020). Researchers such as Suwati, Minarsih and Gagah (2016) have shown that the main goal of work for someone is not only to get the salary, but to reach selfsatisfaction.

However, most organisations have devoted a greater part of economic time and effort to settle conflicts and conflict related issues. This scenario has continued unabated, hence posing a negative challenge to industrial and economic growth of an organisation. Although, scholars like Khan, Hussainy and lqbal (2017 have reasoned that conflict 
Creative Commons User License: CC BY-NC-ND

Abstracted by: EBSCOhost, Electronic Journals Service (EJS),

Google Scholar, Journal Seek, Scientific Commons,

Food and Agricultural Organization (FAO), CABI and Scopus

http://eoi.citefactor.org/10.11226/v25i4
Journal of Agricultural Extension

Vol. 25 (4) October, 2021

ISSN(e): 24086851; ISSN(Print); 1119944X

http://journal.aesonnigeria.org

http://www.ajol.info/index.php/jae

Email: editorinchief@aesonnigeria.org

cannot be completely ruled out in any organization, frequent occurrence of organisational conflict could have an adverse effect on the organisation in terms of lost of production hour, reduction in profits, unemployment and of course reduction in income level of the organisation. Just like any other organisation, the Ogun State AgroServices Corporation is being confronted with various forms of conflict both interpersonal and conflict task conflicts. This will definitely take its toll on the performance of the employees of the corporation and its attendant effect will adversely affect other stakeholders involved in agro-services in the state. This is because when conflict is not properly managed, there cannot be reasonable increase in employees' performance. This study determined the effects of workplace conflict on job performance. Specifically, the study:

(1) examined the workplace conflict experienced by respondents;

(2) determine the respondents' perception of management's resolution strategies on workplace conflict;

(3) determine the job performance of the respondents

\section{Methodology}

The study was carried out in the Ogun State Agro-Service Corporation, Abeokuta, Nigeria. The Ogun State Agro-Services Corporation was established in the month of April, 1980 by law. The corporation covers four (4) geographical zones in the state; namely; Abeokuta (Egba) Zone, Ilaro (Yewa) Zone, ljebu Ode (ljebu) Zone and Ikenne (Remo) Zone. Simple random sampling technique was used to select $50 \%$ of the zones leading to the selection of Abeokuta (Egba Zone) and llaro (Yewa Zone). In Egba and Yewa zones, there were 29 and 6, 12 and 3, 75 and 9, 6 and 5 staff, respectively in the Administrative and Supplies, Finance and Account, Engineering Services Planning and Input departments. Furthermore, $50 \%$ of the members of staff in each department in the two zones were selected using proportionately to size sampling which resulted in 77 respondents.

Data were analysed using percentages and mean. Respondents' perception of management's resolution strategies on workplace conflict was measured with a 5-point Likert-type scale of strongly agree (SA), agree (A), indifferent (I), disagree (D) and strongly disagree (SD) assigned scores of $5,4,3,2$ and 1 respectively for positively worded statements and reserve order for negatively worded statements. While their workplace conflict and job performance were measured using response options of very high $(\mathrm{VH})$, high $(\mathrm{H})$, moderate $(\mathrm{M})$, low $(\mathrm{L})$ and very low $(\mathrm{VL})$ and were assigned scores of $5,4,3,2$ and 1 respectively. The mean score was used to categorize the respondents into having high and low workplace conflict and job performance. A cut-off point of 2.50 was used as bench mark for the statements on the workplace conflict, 
Creative Commons User License: CC BY-NC-ND

Abstracted by: EBSCOhost, Electronic Journals Service (EJS),

Google Scholar, Journal Seek, Scientific Commons,

Food and Agricultural Organization (FAO), CABI and Scopus

http://eoi.citefactor.org/10.11226/v25i4
Journal of Agricultural Extension

Vol. 25 (4) October, 2021

ISSN(e): 24086851; ISSN(Print); $1119944 X$

http://journal.aesonnigeria.org

http://www.ajol.info/index.php/jae

Email: editorinchief@aesonnigeria.org

perception of management's resolution strategies of workplace conflict and job performance.

\section{Results and Discussion}

\section{Workplace Conflict in OGASC}

Table 1 shows that the most prominence indicator in determining workplace conflict experienced by the employees of ASC was the presence of functional staff union to minimize conflict $(\bar{x}=2.99)$. The indicator was also the only indicator that can ameliorate workplace conflict in the list of indicators of workplace conflict has shown in Table 1, which means that its prominence is useful in the reduction in the level of workplace conflict. Hence, it can be implied that the presence of functional staff union in ASC was the most importance indicator when considering factors that can facilitate reduction in workplace conflict.

However, the most deleterious indicator of workplace conflict in the respondents' organization was the existence of favouritism $(\bar{x}=2.51)$. This implies that favouritism is a prominent indicator of occurrence workplace conflict in the ASC. Therefore, issues that relate to favouritism such as jettisoning of merits and denial of rights due to undue preference of some workers over the others by the management are serious escalators of workplace conflict in the organization. most deleterious indicator of workplace conflict in the respondents. This implies that the issue of favouritism, ease of issuing query and ambiguity of job description were the prominent indicators of workplace conflict in ASC. This is line with finding of Isa (2015) which identified favouritism as one of the aggravators of conflict. Although, the existence of favouritism is an indicator of the occurrence of workplace conflict in ASC, it is the only indicator of possible escalation of workplace conflict in the organization. The remaining eight indicators were not prominent indicators of serious workplace conflict in the organization.

Table 1: Workplace conflict in OGASC

\begin{tabular}{lll}
\hline Statement & Mean $(\bar{x})$ & SD \\
\hline Presence of functional staff union to minimize conflict & $2.99^{*}$ & 1.325 \\
Existence of favouritism in the corporation & $2.51^{*}$ & 1.311 \\
Overbearing nature of Superior officers & 2.31 & 1.123 \\
Unacceptable political climate in ASC & 2.30 & 1.139 \\
Ease of issuing query to subordinate staff & 2.30 & 1.266 \\
Management's inability to nip disagreements in the bud & 2.30 & 1.020 \\
Ambiguity of job description in ASC & 2.28 & 1.208 \\
Lack of adequate remuneration and incentives & 2.17 & 1.000 \\
Gross insubordination of lower cadre staff & 2.14 & 1.175 \\
General unhealthy work environment causing co-workers unfriendliness & 1.99 & 0.978 \\
\hline
\end{tabular}

SOURCE: Field Survey, 2016. ${ }^{*}=$ conflict 
Creative Commons User License: CC BY-NC-ND

Abstracted by: EBSCOhost, Electronic Journals Service (EJS),

Google Scholar, Journal Seek, Scientific Commons,

Food and Agricultural Organization (FAO), CABI and Scopus

http://eoi.citefactor.org/10.11226/v25i4
Journal of Agricultural Extension

Vol. 25 (4) October, 2021

ISSN(e): 24086851; ISSN(Print); 1119944X

http://journal.aesonnigeria.org

http://www.ajol.info/index.php/jae

Email: editorinchief@aesonnigeria.org

\section{Perception of Management Resolution Strategies on Workplace Conflict}

Table 2 shows that the respondents perceived all the strategies for the resolution of workplace conflict by the management to be important. Though, there were different levels of the perception of each strategy among respondents. The most favourably perceived management resolution strategies on workplace conflict by the respondents was that the management did not take payment of pension and gratuity with levity $(\bar{x}=4.17)$. Furthermore, the management commending the effort of its outstanding employees $(\bar{x}=4.06)$ and organizing training and development programme for its staff ranked second and third respectively $(\bar{x}=4.00)$. This implies that the respondents believed that the management deployment of the strategies of the avoidance of taking the payment of pension and gratuity with levity which guarantees secured future emoluments, commending effort of outstanding employees and organizing training and development programme for the employees were useful in the resolution of conflicts in the organisation.

While, the least favourably perceived management resolution strategies on workplace conflict by the respondents was that the management does not engage in favouritism among its workforce $(\bar{x}=2.82)$. The implication is that the respondents are of the opinion that the management had not done enough in curtailing the issue of favouritism in the organisation. This is in concordant with the most deleterious indicator of workplace conflict expressed by the respondents.

Table 2: Perception of management resolution strategies on workplace conflict

\begin{tabular}{lll}
\hline Statement & Mean & SD \\
\hline Payment of pension and gratuity not with levity & $4.17^{*}$ & 1.253 \\
Commends the efforts of its outstanding employees & $4.06^{*}$ & 0.982 \\
Organizes training and development programme & $4.00^{*}$ & 1.005 \\
Timely resolution of conflict within ASC & $3.97^{*}$ & 1.072 \\
Provides an enabling environment to achieve goals & $3.92^{*}$ & 1.066 \\
Encourages the flow of new ideas from the employees & $3.91^{*}$ & 0.928 \\
Employee are carried along in decision making process & $3.88^{*}$ & 1.159 \\
Providing a good physical environment for its staff & $3.86^{*}$ & 1.064 \\
Prompt decision on employees' welfare & $3.81^{*}$ & 1.134 \\
Policy on provision of soft loan to its employees is favourable & $3.54^{*}$ & 1.088 \\
Do not provide equal opportunities for its employees & $3.16^{*}$ & 1.291 \\
Does not engage in favouritism among its workforce & $3.07^{*}$ & 1.074 \\
Management encourages personal development of its employees & $2.82^{*}$ & 1.387 \\
\hline
\end{tabular}

SOURCE: Field Survey, 2016. ${ }^{*}=$ Strategy 
Creative Commons User License: CC BY-NC-ND

Abstracted by: EBSCOhost, Electronic Journals Service (EJS),

Google Scholar, Journal Seek, Scientific Commons,

Food and Agricultural Organization (FAO), CABI and Scopus

http://eoi.citefactor.org/10.11226/v25i4
Journal of Agricultural Extension

Vol. 25 (4) October, 2021

ISSN(e): 24086851; ISSN(Print); 1119944X

http://journal.aesonnigeria.org

http://www.ajol.info/index.php/jae

Email: editorinchief@aesonnigeria.org

\section{Job Performance}

The results in Table 3 reveal that the highest indicator of job performance among the respondents was productive working relationship with others $(\bar{x}=4.11)$. The second in rank among the indicators was the team spirit exhibited by the respondents $(\bar{x}=4.01)$ and followed by sense of working to meet time frame ( $\bar{x}=3.99)$. Therefore, it could be inferred that productive working relationship with others, team spirit and sense of working to meet time frame were the foremost important aspects of the job performance of the respondents. Furthermore, the three aspects indicates that in improving the job performance of the respondents, it is necessary to reinforce respondents' productive working relationship, team spirit and sense of working to meet time frame. The finding of Pradhan and Jena (2016) alluded to the fact that completing assignment on time is an indicator of job performance.

Table 3 further shows that the lowest indicator of respondents' job performance was their timelessness in operation $(\bar{x}=3.69)$. This indicates low interest of the respondents in devoting extra time to their job beyond the stipulated time for doing their job. Hence, it further suggests that a lot needs to be done in order to encourage the respondents to develop the sense of devoting extra time to performing their jobs when necessary.

Table 3: Job performance in OGASC

\begin{tabular}{lll}
\hline Statement & Mean $(\bar{x})$ & SD \\
\hline Productive working relationships with others & $4.11^{*}$ & 0.865 \\
Team work spirit in the corporation & $4.01^{*}$ & 0.920 \\
Sense of working to meet time frame & $3.99^{*}$ & 0.886 \\
Dutifulness of employees & $3.94^{*}$ & 0.893 \\
Sense of managing disseminating information & $3.92^{*}$ & 0.997 \\
Flexibility in job dictate & $3.83^{*}$ & 1.084 \\
Sense of consolidating on organisational achievements & $3.82^{*}$ & 0.762 \\
Spirit of working beyond expectation & $3.75^{*}$ & 1.077 \\
Sense of reasoning to inject new ideas into the corporation & $3.71^{*}$ & 0.978 \\
among employees & & \\
Timelessness in operation of employees & $3.69^{*}$ & 1.149 \\
\hline
\end{tabular}

Source: Field Survey, 2016. ${ }^{*}=$ job performance

\section{Conclusion and Recommendations}

Workplace conflict in the respondents' organization was not serious to the level of impairing their job performance drastically. Furthermore, the job performance of the respondents was good. Although, there is still need for the reduction of workplace conflict in the respondents' organization, the respondents experienced low workplace conflict. However, the respondents are not favourably disposed to the management's resolution strategies on workplace conflict. Therefore, the management of OGASC 
Creative Commons User License: CC BY-NC-ND

Abstracted by: EBSCOhost, Electronic Journals Service (EJS),

Google Scholar, Journal Seek, Scientific Commons,

Food and Agricultural Organization (FAO), CABI and Scopus

http://eoi.citefactor.org/10.11226/v25i4
Journal of Agricultural Extension

Vol. 25 (4) October, 2021

ISSN(e): 24086851; ISSN(Print); $1119944 X$

http://journal.aesonnigeria.org

http://www.ajol.info/index.php/jae

Email: editorinchief@aesonnigeria.org

should ensure improvement in the deployment of the used resolution strategies to drastically reduce conflict. In addition, the management of OGASC should ensure that indicators of conflict such as favouritism are eliminated or reduced to the barest minimum in the organisation.

\section{References}

Hee, O. C., Shi, C. H., Kowang, T. O., Fei, G. C. and Ping L. L. (2020). Factors affecting job satisfaction among academic staffs. International Journal of Evaluation and Research in Education (IJERE), 9(2), 285-291.

Isa, A. A. (2015). Conflicts in organisations: Causes and consequences. Journal of Educational Policy and Entrepreneurial Research (JEPER), (2) 11, 54-59.

Khan, K., Hussainy, S. K. and lqbal, Y. (2017). Causes, effects and remedies in conflict management. The South East Asian Journal of Management, 10 (2).

Md. Zahid, H. (2017). The Impact of organisational conflict on employees' performance in private commercial banks of Bangladesh. IOSR Journal of Business and Management (IOSR-JBM) 19(10),12-21.

Oachesu, M. (2016). Conflict management, a new challenge.3rd Global Conference on Business, Economics, Management and Tourism, 26-28 November 2015, Rome, Italy.

Osborne, S. and Hammoud, M. S. (2017). Effective employee engagement in the workplace. International Journal of Applied Management and Technology, 16(1), 50-67.

Pradhan, R. K. and Jena, L. K. (2016). Employee performance at workplace: Conceptual model and empirical validation. Business Perspectives and Research, 5 (1).

Suwati, Magdalena, M., Gagah, E. (2016). Influence of motivation work, career development and cultural organisation on the job satisfaction and implications on the performance of employees. Journal of Management, 2 (2).

Utaka, P. F. and Silas-Dibiko, I. D. (2020). Conflict management and conflict skills needed in educational tertiary institutions in Nigeria. International Journal of Social Sciences and Management Research, 6(4). 